\title{
The accuracy of body weight estimation in Fat Tailed Sheep based on linear body measurements and tail circumference
}

\author{
Sucik Maylinda*, and Woro Busono \\ Animal Productin Department, Faculty of Animal Science, \\ University of Brawijaya, Malang \\ Jalan Veteran, Malang (65145) Indonesia
}

Submitted: 5 July 2019, Accepted: 5 August 2019

\begin{abstract}
The aim of the research was to determine the accuracy of the estimation of DEG body weight based on linear measurements (chest circumference/ CC, tail circumference/ TC, body length/ $\mathrm{BL}$, and body height/ $\mathrm{BH}$ ). The research is expected to produce a model of DEG body weight estimation based on linear measurements (CC, BL, BH and tail circumference/ TC). Material used in this research was male fat tailed sheep which has different age seen from the change of permanent teeth PI0, PI1, PI2. The total number of animal used in this research was 60 with details of PIO $=30$, $\mathrm{PI} 1=24$ and PI2 $=6$. Data were analysed by Linear and Multiple Regression Analysis between Body weight and BCS, Linear measurements (CC, BL, BH and TC), using Minitab software version 13. 1. All variables of linear measurements of the body have a strong relationship with body weight, the strongest relationship is body weight with chest circumference, and tail circumference. Estimation of body weight using multiple regression functions $(\mathrm{BW}=-18.7+0.408 \mathrm{BH}+0.172 \mathrm{BL}+0.274 \mathrm{CC}+$ $0.178 \mathrm{TC}$ ) has an accuracy higher than the estimated body weight using the Schoorl formula.
\end{abstract}

Keywords: fat tailed sheep; body weight estimation; linear measurements; multiple regression.

"Corresponding Author: sucik@ub.ac.id 


\section{INTRODUCTION}

Fat Tailed Sheep (DEG) is a local sheep that are mostly raised in East Java. It is a sheep with a thick tail characteristic filled with fat tissue. It is a good meat type lamb originating in Southwest Asia that was brought by Gujarat traders in the 18th century to the Lamongan area of East Java, Madura Island and arrived at Sapudi Island, and subsequently developed from generation to generation by the community. So far this DEG keeping is still traditional, in which case the advances in science and technology have never been touched. With high adaptability to low feed quality and hot ambient temperatures, these sheep develop into quite potential meat cattle. The characteristics of DEG are divided into two, namely (1) qualitative characteristics that involve specific characteristics and quantitative characteristics. That is concerning the production capability and growth(1) Qualitative characteristics (for adult adult sheep) 1) color: a) body: dominant white. b) head: White. 2) face line: A little convex. 3) ears: Large enough, long, wide, and upright to the side at an angle of 45-90 degrees. 4) horns: No horns. 5) back line: concave curve with elevated back. 6) tail: varies from triangular to sigmoid, thick, long and wide, the middle part is wide and often winding (sigmoid) and tapered at the end. 7) temperament: calm and not aggressive. b. (2) Quantitative characteristics (adults): 1) body surface size: a) shoulder height: male: $70.4 \pm 4.2 \mathrm{~cm}$. Females: $58 \pm 2.4 \mathrm{~cm}$. b) body length: Male: $70 \pm 5.1 \mathrm{~cm}$. Females: $58.4 \pm 4 \mathrm{~cm}$. c) chest circumference: Male: $84.8 \pm 4.3 \mathrm{~cm}$. Females: $67.8 \pm 6.1 \mathrm{~cm}$. 2) body weight: male: $44.6 \pm 6.2 \mathrm{~kg}$. Females: $25.8 \pm 5.7 \mathrm{~kg}$ (Directorate of Breeding and Animal Production, 2015). This potential makes sheep very likely to become the mainstay meat of Indonesia, amid the difficulty of increasing the cattle population as a provider of meat. With such excellence, this local sheep needs to be increased in productivity. To increase productivity, body measurements and body weight data are needed, especially in locations that are difficult to reach. On the other hand, the improvements so far are still not comprehensive, not based from scientific data. Therefore, a research is needed that measures body measurements of fat tailed sheep in the field as a basic of genetic improvements.

DEG maintenance in the villages is quite varied with traditional maintenance management causing a lack of body data from weighing results in the field. This is due to the lack of measurement facilities in the field and the difficulty of topography of the measurement locations, so that alternatives are needed to do the weighing. Various methods have been developed to measure body weight of sheep, namely through the way estimates (estimates) based on measures that are easier to measure, for example linear measurements of the body (chest circumference/ CC, body length (BL), body height (BH). For DEG, sheep body weight estimation has also been developed based on the Tail Circumference, because in reality DEG has a fat tail, the middle base is wide and winding (sigmoid) and tapered at its end. The correlation of tail circumference with body weight in female fat tail sheep is strong with a correlation of 0.719 in adult sheep, while for lamb is 0, 932 and for the older sheep as thick as 0.619 , while in rams the correlation coefficient is higher (Islamiah, 2016).

The aim of the research was to determine the accuracy of the estimation of DEG body weight based on linear measurements (chest circumference, tail diameter, body length, and body height). The research is expected to produce a model of DEG body weight estimation based on linear measurements $(\mathrm{CC}, \mathrm{BH}$ and $\mathrm{BL})$ and tail circumference (TC). The results of this research are expected to be used as a basis for genetic improvement of Fat Tailed Sheep in Indonesia. 


\section{MATERIAL AND METHOD}

Material used in this study was male fat tailed sheep which has different age seen from the change of permanent teeth PI0, PI1, PI2. The total number of animal used in this research was 60 with details of $\mathrm{PIO}=$ $30, \mathrm{PI} 1=24$ and PI $=6$.

The equipment used in this research included : 1). Measuring tape; used to measure tail circumference and chest circumference, with a precision scale of $0.1 \mathrm{~cm} ; 2$ ). Measuring stick; to measure height and body length, with a precision scale of 0.1 $\mathrm{cm}$; and 3). Digital scales; used to weigh fat body tail sheep, with a precision scale of $0.1 \mathrm{~kg}$.

The method used in this study was survey and correlational methods carried out at the Agrilestari Dairy Farm with a total of 60 male DEGs aged $\pm 1-2$ years and direct observation in the field. Samples were taken using purposive sampling technique, which wass sampling based on particular considerations which include body size and age difference of animals.

\section{Observation variables}

The measured body parts of the sheep include vital statistics (body length, chest circumference and height) and tail circumference. The variables observed included: Tail Circumference measured circularly in the largest part and the middle part of the tail circumference.

1. Linear measurements or Vital Statistics is measured by a measuring pin:

a. Chest circumference (CC) is measured in a circle just behind the shoulder past the gumba.

b. Body length (BL) is measured horizontally from the front edge of the shoulder joint (bone scapula) to the back edge of the bone of the sitting bone.

c. Height $(\mathrm{BH})$ is measured perpendicular to the back or back of the dolphin to the ground or floor.

d. Tail circumference (TC).
The methods to measure vital statistics can be seen at Figure 1.

2. Body Weight (BW) is measured by digital scales in units of $\mathrm{kg}$.

3. Livestock age (grouping factor) is estimated by looking at the number of points in livestock teeth distinguished by changes in permanent teeth PI0, PI1, PI2 (Permanent Incicivi).

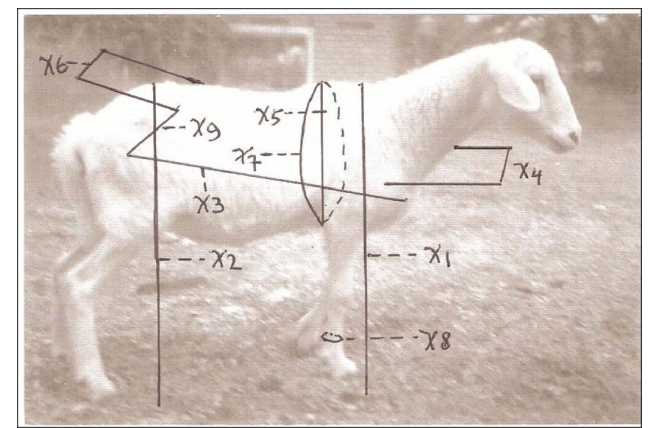

Figure 1. Measurement of body height/ $\mathrm{BH}$

(X1), Body length/ BL (X3) and Chest circumference/ CC (X7)

(Source : Inounu, Razavi and Mulyono, 2009).

\section{Data Analysis}

Data were analysed by Linear and Multiple and Regression Analysis between Body weight and BCS, Linear measurements (CC, BL and $\mathrm{BH}$ ) and $\mathrm{TC}$, using Minitab software version 13. 1. In this research also calculate the difference between real body weight and estimated body weight or called as Correction Factor according to Kusuma, Ngadiyono and Sumadi (2017).

$$
\text { Correction Factor }=\frac{\text { RBW-EBS }}{\text { RBW }} \times 100 \%
$$

\section{RESULT AND DISCUSSION}

Body weight, chest circumference, body length, body height and tail circumference

Description about the average of the variables are shown at Table 1 . From these results it seems even though the results of linear body measurements are from measurements in the field, but the variation (see CV) is still reasonable. 
Table 1. Body weight (BW), Body height (BH), Chest cirumference (CC), Body length (BL) and tail circumference (TC)

\begin{tabular}{ccc}
\hline Variables & Mean \pm sd & CV $(\%)$ \\
\hline BW $(\mathrm{kg})$ & $24.73 \pm 2.32$ & 9.38 \\
BH $(\mathrm{cm})$ & $23.74 \pm 0.93$ & 3.92 \\
CC $(\mathrm{cm})$ & $72.80 \pm 3.25$ & 4.46 \\
BL $(\mathrm{cm})$ & $56.15 \pm 4.12$ & 7.34 \\
TC $(\mathrm{cm})$ & $23.18 \pm 3.18$ & 13.72 \\
\hline
\end{tabular}

\section{Relationship between Body Weight (BW) and all variables}

Body weight measurement is essential for any breeding and selection programme, feeding, vaccination and drug dosage in livestock industry. So estimation of body weight estimatetion is very important both in big commercial farm and small scale traditional farm in the village. In the village, it is difficult to do body weight measurement because it is difficult to find animal scaler especially for big animals like cattle, goat or sheep. The researchers found high phenotypic correlations between body weight and chest girth in those animals. It can also be used to assess growth rate, feed utilization and carcass characteristics in farm animals (Olawumi and Farinnako, 2017).

\section{Simple Correlation and Regression}

Table 2. The correlation between body weight (BW) and chest circumference (CC), body length (BL), body height (BH) and tail cirumference (TC)

\begin{tabular}{ccc}
\hline Variables & Body weight & Level of significance *) \\
\hline CC $(\mathrm{cm})$ & 0.55 & 0.001 \\
BL $(\mathrm{cm})$ & 0.36 & 0.005 \\
BH $(\mathrm{cm})$ & 0.38 & 0.003 \\
TC $(\mathrm{cm})$ & 0.45 & 0.001 \\
\hline
\end{tabular}

*) the lower level means more accurate

\section{Regression Line}

Table 3. The linear regression between body weight (BW) and chest circumference (CC),body length (BL), body height (BH) and tail cirumference (TC)

\begin{tabular}{lll}
\hline Regression line & $\mathrm{R}^{2}(\%)$ & Level of significance \\
\hline $\mathrm{BW}=-3,63+0,390 \mathrm{CC}$ & 29.7 & 0.001 \\
$\mathrm{BW}=13,3+0,204 \mathrm{BL}$ & 13.1 & 0.05 \\
$\mathrm{BW}=1,90+0,962 \mathrm{BH}$ & 14.7 & 0.03 \\
$\mathrm{BW}=17,2+0,327 \mathrm{TC}$ & 19.9 & 0.001 \\
\hline
\end{tabular}

$\mathrm{R}^{2}=$ determination coefficient

Table 3 showed that all variables have very close relationship with body weight, especially chest circumference (CC) and tail circumference (TC). This is consistent with Malewa (2009) study on Donggala sheep; Basbeth, Dilaga and Purnomoadi (2015) in Jawarandu goats; Afolayan, Adeyinka and Lakpini (2006) in Yakansa sheep who reported that chest circumference had the highest and very strong correlation coefficient value of 0.91 ; $0.93 ; 0.94$. This is presumably because the chest circumference is directly related to the chest and abdomen. Many researchs reports the same result, for example Tama, Nasich and Wahyuningsih (2016) reported the correlation between body weight and body measurements ranged from 0.90 to 
0.97. The highest correlation values were found between body weight and chest circumference $(0.97, \mathrm{p}<0.01)$. Correlation and regression analysis were applied to estimate the relationship among these traits. The study concluded that body weight had a strong correlation with chest circumference (0.97), body length (0.92), and body height (0.90).

The relationship between body weight and linear measurements in this research is also consistent with other research with different species, for example research report of Gambo, Momoh and Dim and Kosshak (2014) in Japanese quail, it was found that all variables (body weight, body length, wing length, breast girth, shank length) have medium to high correlation with body weight. In Bali cattle, chest circumference is high correlated with weaning weight $(\mathrm{r}=$ $0.847)$ and yearling weight $(\mathrm{r}=0.87)$ (Gunawan and Jakaria, 2010). It was also reported that the relationship between chest circumference and body weight in pregnant goat was strong $(r=0.73)$ (Rifa'i, Surjowardojo and Susilorini, 2019).

\section{Multiple Regression}

To estimate body weight based on linear measurements (BH, BL, CC and TC) is presented in Table 4.

Table 4. Multiple regression between body weight and all variables

\begin{tabular}{lll}
\hline Regression line $*)$ & $\mathrm{R}^{2}(\%)$ & Level of significance \\
\hline $\mathrm{BW}=-18.7+0.408 \mathrm{BH}+0.172 \mathrm{BL}+0.274 \mathrm{CC}+0.178 \mathrm{TC}$ & 49.0 & 0.001 \\
\hline$*) \mathrm{BW}=\begin{array}{l}\text { Bodyweight, } \mathrm{BH}=\text { body height, } \mathrm{BL}=\text { body length, } \mathrm{CC}=\text { Chest circumference, } \mathrm{TC}=\text { tail } \\
\text { circumference, } \mathrm{R}^{2}=\text { determination coefficient }\end{array}$
\end{tabular}

\section{Analysis Each Component of Multiple Regression}

Table 5. The level of significance of each component variables of multiple regression

\begin{tabular}{cc}
\hline Variables & Level of significance \\
\hline CC & 0.001 \\
BL & 0.003 \\
BH & $\left.0.127^{*}\right)$ \\
TC & 0.024 \\
\hline
\end{tabular}

Based on the data analysis of each variable which is a component of multiple regression functions, it seems that all variables (CC, BL, and TC) are very significantly correlated with body weight (BW) except body height (BH). The same result is also obtain by Farahani, Shahrbabak, Shahbabak and Yeganeh, 2010) that relationship between linear body measurements and tail circumference is quite strong $\left(\mathrm{R}^{2}\right.$ was $\left.69 \%\right)$

\section{Analysis of differences in real body weight with estimated body weight}

The difference between real body weight and estimated body weight using regression line resulted from this research $(\mathrm{BW}=-18.7+0.408 \mathrm{BH}+0.172 \mathrm{BL}+$ $0.274 \mathrm{CC}+0.178 \mathrm{TC}$ ) shows a very small difference $(0.0042 \mathrm{~kg})$. When compared with estimated body weight using the Schoorl formula (Malewa, 2009), the difference between actual body weight and estimated body weight is still smaller $(0.0042 \mathrm{~kg}$ vs. $0.18 \mathrm{~kg})$, or $(0.04 \% \mathrm{VS}$ $0.764 \%)$. When compared between the estimated body weight of this research with estimated body weight using the Schoorl formula, this results of this research is closer with real body weight (see tables 1 and 6). 
Table 6. The comparison between the differences of real body weight and estimated body weight of this research and the differences of real body weight and the estimated body weight by Schoorl equation.

\begin{tabular}{lc}
\hline Variables & Mean \pm SD $(\mathrm{kg})$ \\
\hline Estimated weight of this research & $24.72 \pm 1.63$ \\
Estimated weight based on Schoorl & $29.02 \pm 1.99$ \\
\hline
\end{tabular}

Results of data analysis showed that the accuracy of body weight estimation based on multiple regression results of this study $(\mathrm{BW}=-18.7+0.408 \mathrm{BH}+0.172 \mathrm{BL}+$ $0.274 \mathrm{CC}+0.178 \mathrm{TC}$ ) was higher than that produced by the Schoorl formula.

\section{CONCLUSION}

All variables of linear measurements of the body have a strong relationship with body weight, the strongest relationship is body weight with chest circumference, and tail circumference. Estimation of body weight using multiple regression functions study $(\mathrm{BW}=-18.7+0.408 \mathrm{BH}+0.172 \mathrm{BL}+$ $0.274 \mathrm{CC}+0.178 \mathrm{TC})$ has an accuracy higher than the estimated body weight using the Schoorl formula.

\section{REFERENCES}

Afolayan, R. A., I. A. Adeyinka and C. A. M. Lakpini. 2006. The esti-mation of live weight from body measurements in Yankasa sheep. Czech $J$. Anim. Sci., 51(8), 343-348.

Basbeth A.H., W.S. Dilaga and A. Purnomoadi., 2015. The Correlation between body measurements and body weight of young male Jawarandu goats of Kendal Distric, (Central Java). Animal Agriculture Journal, 4(1), 355-360.

Institute for Animal Production (IRIAP). 2015. Garut Composite Sheep. Indonesian Agency for Agricultural Research and Development. Ministry of Agriculture

Farahani, A.H.K, Shahrbabak, H.M, Shahrbabak, M.M, Yeganeh. 2010. Relationship of fat-tail and body measurements with some economic important traits in fat-tail Makoei breed OF Iranian sheep. African Journal of Biotechnology, 9(36), 5989-5992.

Gambo, D, Momoh OM, Dim NI., and Kosshak AS. 2014. Body parameters and prediction of body weight from linear body measurements in Coturnix quail. Livestock Research for Rural Development, 26(6), 1-5. http://www.lrrd.org/lrrd26/6/daud26 $\underline{110 . h t m l}$

Gunawan, A. and Jakaria. 2010. Application of Linear Body Measurements for Predicting Weaning and Yearling Weight of Bali Cattle. Animal Production, 12(3), 163-168.

Inounu, I. Razavi, E. and Mulyono, R. 2009. Characteristic of body measurement and shape of Garut sheep and its crosses with other breeds Characteristics of Body Measurement and Shape of Garut Sheep and Its Crosses with Other Breeds. American Journal of Animal and Veterinary Sciences, 14, 295-306.

Islamiah J.P. 2016. Korelasi antara Ukuran Ekor dengan Bobot Badan pada Domba Ekor Gemuk. Hal. 1-15.

Kusuma, SB, Ngadiyono, N. and Sumadi. 2017. The Correlation of Body Measurements and Weights of Ongole Crossbred (PO) Cattle in Kebumen Regency. The 7-th International Seminar on Tropical Animal Production, September 12-14, Yogyakarta. 
Malewa, A., 2009, Penaksiran Bobot Badan Berdasarkan Lingkar Dada dan Panjang Badan Domba Donggala., J. Agroland, 16(1), 91-97.

Olawumi, S. and Farinnako, A. 2017. Evaluation of the Relationship between Body Weight and Linear Measurements in West African Dwarf Goat as Influenced by Sex and Agrovegetational Zone. Science International, 5(2), 63-67.

Rifa'i, Surjowardojo,P, and Susilorini, T.E. 2019. The Relationship between Vi- tal Statistics with Pregnant Body Weight of Etawah Cross Bred Goat in Malang District, Indonesia. International Research Journal of Advanced Engineering and Science. ISSN (Online): 2455-9024.

Tama, W.A., Nasich .M dan Wahyuningsih S. 2016. Hubungan antara lingkar dada, panjang dan tinggi badan dengan bobot badan kambing Senduro jantan. Jurnal Ilmu Ilmu Peternakan, 26(1), 37-42. 